\title{
ANTARA ZAINICHI DAN PACHINKO: REPRESENTASI ZAINICHI KOREA DALAM NOVEL PACHINKO KARYA MIN JIN LEE
}

\author{
Febriani Elfida Trihtarani, M. Mahbubdin Ridha Alfasya, Nurussofa Yusticia, Nining Setyaningsih \\ Bahasa dan Kebudayaan Korea, Fakultas Ilmu Budaya, Universitas Gadjah Mada \\ febrianielfida08@ugm.ac.id
}

\begin{abstract}
Abstrak
Penelitian ini membahas representasi zainichi Korea dalam novel Pachinko karya Min Jin Lee. Terdapat beberapa kategori dari zainichi Korea dalam masyarakat Jepang, yaitu pluralis, nasionalis, individualis, dan asimilasionis. Generasi pertama dalam novel ini mendapatkan perlakuan tidak setara akibat etnis mereka yang menyebabkan mereka harus hidup di kawasan kumuh. Generasi kedua direpresentasikan oleh dua tokoh yang saling berkebalikan. Tokoh Noa memiliki keinginan untuk menjadi seorang "Jepang" yang pada akhirnya memilih jalan naturalisasi. Melalui jalan naturalisasi tokoh ini dapat dianggap sebagai seorang asimilasionis yang meninggalkan identitas etnisnya dan hidup sebagai seorang warga Jepang untuk mendapatkan status sosial yang setara. Tokoh Mozasu memiliki kecenderungan berkebalikan dengan Noa karena ia tidak memilih jalan naturalisasi dan tetap mempertahankan identitas aslinya sebagai orang Korea. Generasi ketiga masih mendapat ketidakpastian identitas meskipun mereka lahir dan besar di Jepang. Dengan pendidikan yang Solomon dapatkan, ia masih tetap dipandang sebelah mata dan masih dianggap tidak berada di posisi yang setara dengan orang Jepang. Bisnis pachinko yang selalu diasosiasikan dengan pendatang Korea adalah bisnis, yang ditekuni oleh masing-masing tokoh generasi kedua bahkan ketiga, menunjukkan bahwa status zainichi Korea tidak akan semudah itu berubah dan mereka akan tetap berada dalam posisi marjinal yang dipandang sebelah mata.
\end{abstract}

Kata kunci: pachinko, zainichi, krisis identitas, Korea, Jepang

\begin{abstract}
This study discusses the representation of Korean zainichi in Pachinko novel by Min Jin Lee. There are several categories of Korean zainichi amongst Japanese society, which are pluralist, nationalist, individualist, and assimilationist. The first generation in this novel is treated unfairly because of their ethnicity which makes them live in slum area. The second generation is represented by two contradictive characters. The first character, Noa, wants to be Japanese, which leads him to choose the path of naturalization. Through naturalization, this character is regarded as an assimilationist who ignores his ethnic identity and lives as a Japanese citizen to obtain equal social status. Meanwhile, the second character, Mozasu has the opposite tendency of Noa's. He does not choose the path of naturalization and tends to maintain his true identity as a Korean. The third generation is left uncertain about their identity, although they were born and grow up in Japan. With his background education, Solomon as a third-generation is still underestimated and considered unequal to Japanese people. The pachinko business, which is always being associated with Korean migrants, is a business occupied by each of the second and third generation characters, showing that the status of Korean zainichi will not change easily, and they will remain in marginal position and being underestimated.
\end{abstract}

Keywords: pachinko, zainichi, identitiy crisis, Korea, Japan 
Poetika: Jurnal Ilmu Sastra

Vol. VII No. 2, Desember 2019
DOI 10.22146/poetika.51208

ISSN 2338-5383 (print); 2503-4642 (online)

\section{Pendahuluan}

Secara harfiah, zainichi berarti 'tinggal di Jepang' dan dapat digunakan untuk menunjuk orang asing yang tinggal di Jepang. Namun, kata zainichi secara khusus banyak digunakan untuk menyebut masyarakat pendatang dari Semenanjung Korea dan keturunannya yang menetap di Jepang (Lie dalam Morooka, 2016). Secara historis, zainichi Korea mulai bermigrasi ke Jepang sejak masa penjajahan Jepang di Korea, yaitu antara 1910 sampai 1945. Pada saat Perang Dunia ke-2 berakhir, beberapa persen pendatang dari Korea tersebut kembali ke Korea, tetapi sekitar 600.000 orang memilih untuk menetap di Jepang (Cho, 2016). Para pendatang Korea yang menetap di Jepang selepas perang berakhir lebih banyak berasal dari bagian selatan Semenanjung Korea (Ryang, 2014).

Penampilan luar yang tidak mudah dibedakan secara sekilas dengan orang Jepang, maupun penggunaan bahasa Jepang yang sangat fasih untuk berkomunikasi, membuat populasi pendatang dari Korea melebur dengan sangat mudah dengan penduduk lokal Jepang. Akan tetapi, hal ini tidak membuat mereka lepas dari prasangka dan juga diskriminasi orang-orang Jepang. Bahkan, banyak dari mereka yang mengalami kebingungan identitas. Krisis identitas inilah yang menjadi konflik internal yang tidak dapat dilepaskan dari komunitas ini (Fukuoka dalam Lee, 2017: 50).

Pengalaman hidup zainichi Korea yang tidak lepas dari diskriminasi serta krisis identitas yang tidak terelakkan inilah yang diangkat oleh salah seorang penulis Korea yang tinggal dan besar di Amerika, Min Jin Lee, dalam novel populernya: Pachinko. Novel ini berfokus pada kehidupan empat generasi keluarga Korea pada masa penjajahan Korea periode 1910 sampai 1930-an dan kehidupan mereka setelah bermigrasi ke Jepang pada 1930-an hingga 1989. Rentang waktu 70 tahun ini terbagi dalam tiga bagian. Bagian pertama berfokus pada keluarga Sunja, yang sekaligus menjadi tokoh utama dalam novel ini. Bagian kedua dan ketiga berfokus pada kehidupan Sunja setelah berpindah ke Osaka, Jepang, pada 1930an dan termasuk bagaimana ia menjadi generasi pertama zainichi Korea di Jepang.

Secara historis, generasi pertama zainichi harus menerima diskriminasi yang tidak hentinya dari masyarakat lokal disebabkan latar belakang etnis dan status sosial mereka. Bahkan, generasi kedua zainichi pun harus menerima perlakuan yang serupa meskipun mereka lahir dan besar di Jepang. Mereka harus bertahan di tengah stereotip dan pandangan tentang etnis mereka serta diperlakukan tidak setara dalam masyarakat. Stereotip, status sosial yang tidak setara, hingga diskriminasi inilah yang menyebabkan munculnya krisis identitas dari dalam setiap generasi zainichi. Hal yang terjadi di dalam sejarah pun tecermin dalam novel Pachinko yang digunakan sebagai objek dalam penelitian ini. Poin yang hendak ditekankan oleh Min Jin Lee dalam novel ini juga dihubungkan dengan kata "pachinko" yang menjadi judul novel. Generasi pertama hingga ketiga zainichi Korea dalam novel ini memiliki keterkaitan yang erat dengan "pachinko", yang membuat hal ini menarik untuk diteliti dan 
dikaji lebih dalam.

Kata pachinko yang dipilih sebagai judul novel ini diambil dari permainan judi populer yang berasal dari Jepang. Bisnis pachinko dianggap sebagai bisnis "tidak bersih" yang berkembang di kawasan yang kumuh dan terutama banyak dioperasikan oleh para pendatang, termasuk di dalamnya pendatang dari Korea. Etnis Korea bahkan mendulang kesuksesan di bisnis pelayanan, seperti kabaret, bisnis restoran, dan juga bisnis pachinko. Hal ini terjadi karena ketidaksetaraan yang mereka terima dalam masyarakat Jepang dan juga diskriminasi yang mereka dapatkan. Bisnis-bisnis di bidang tersebut merupakan hasil dari pengucilan mereka dari bidangbidang industri lainnya sebagai etnis pendatang yang berasal dari Korea. Zainichi Korea tidak dapat bekerja di sektor umum hingga tahun 1972 sehingga mereka harus bertahan hidup dalam bisnis-bisnis "rendahan" di masyarakat (Chan, 2018). Di dalam novel ini pun, bisnis pachinko menjadi sumber penghasilan beberapa tokoh utama yang termasuk ke dalam generasi kedua, yaitu Noa dan Mozasu. Terjunnya kedua tokoh ini ke dalam bisnis pachinko tidak jauh dari fakta sejarah yang telah disebutkan, yaitu sebagai akibat dari diskrimasi dan pengucilan yang mereka terima dari masyarakat. Diskriminasi inilah yang pada akhirnya menyebabkan munculnya krisis identitas yang dirasakan oleh beberapa tokoh zainichi Korea dalam novel Pachinko.

Berkaitan dengan krisis identitas zainichi, Fukuoka dan Tsujiyama (dalam Lee, 2012: 7) membagi identitas zainichi Korea ke dalam empat bentuk kelompok, yaitu pluralis, nasionalis, individualis, dan asimilasionis. Para pluralis dapat didefinisikan sebagai para zainichi yang cenderung memilih untuk tidak menolak identitas etnis mereka dalam kehidupan sehari-hari. Sebagian besar zainichi yang pluralis tetap memiliki dan menjaga nama asli Korea mereka sekalipun beberapa dari mereka memilih jalan naturalisasi, yaitu berganti kewarganegaraan. Sementara zainichi yang cenderung nasionalis adalah mereka yang tetap menjunjung tinggi identitas etnis mereka dan menolak naturalisasi karena dianggap sebagai pengkhianatan terhadap nenek moyang dan juga identitas etnis mereka.

Adapun individualis lebih menekankan pada kesuksesan ekonomi dan finansial serta bersikap tak acuh mengenai identitas mereka sebagai zainichi. Sementara itu, para asimilasionis adalah mereka yang menolak identitas etnis asli mereka dan memilih jalan naturalisasi untuk dapat hidup sebagai "orang Jepang" dengan kewarganeraan Jepang. Konsep identitas tersebut tecermin dalam tokoh-tokoh utama novel Pachinko dari generasi pertama hingga ketiga. Dalam novel ini, krisis identitas yang mereka hadapi dideskripsikan sebagai sesuatu yang sangat memengaruhi keseharian mereka. Terlebih lagi, krisis identitas tersebut juga berkaitan erat dengan judul "pachinko" karena bisnis pachinko inilah yang menjadi salah satu bukti tidak terelakkannya lagi ketidaksetaraan yang dialami oleh setiap generasi zainichi di Jepang.

Penelitian ini menggunakan metode penelitian kualitatif yang difokuskan pada datadata dalam novel yang berupa dialog dan juga 
narasi para tokoh. Data tersebut digunakan untuk mencari bentuk krisis identitas yang dialami oleh tokoh zainichi di dalam novel ini sesuai dengan pendapat Fukuoka dan Tsujiyama (dalam Lee, 2012). Dengan mencari sumber pendukung yang berkaitan dengan sejarah dan penelitian sebelumnya tentang zainichi Korea, novel ini dibaca kemudian dicari representasi generasi zainichi Korea pertama hingga ketiga yang mengalami perlakuan tidak setara dalam masyarakat serta krisis identitas yang kemudian dianalisis dan dikaitkan dengan bisnis pachinko yang menjadi fokus utama dalam novel. Hasil analisis dalam penelitian ini akan dijabarkan berdasarkan periode, yaitu dimulai dari generasi pertama, kedua, hingga ketiga.

Sejauh ini, penelitian yang mengkaji novel Pachinko adalah oleh Yim Jin-hee (2019) yang berjudul "Place Discourse of Koreans in Japan: Min Jin Lee's Pachinko". Penelitian ini mengkaji novel Pachinko sebagai teks sastra yang mengusulkan kepedulian terhadap kewarganegaraan secara global untuk dapat mencapai visi peradaban yang empatik. Penelitian ini menyebutkan bahwa diskusi mengenai politik di dalam sastra pada akhirnya membuka jalan peningkatan nilainilai demokrasi eksistensi dari warga negara global dan juga perluasan dalam kesadaran global tentang kehidupan manusia dalam keberlangsungan masa depan manusia pada masa mendatang. Penelitian ini berfokus menganalisis wacana ruang dalam novel $\mathrm{Pa}$ chinko yang dikaitkan dengan beberapa tokoh yang muncul. Hanya, penelitian ini belum membahas alasan bisnis pachinko diambil sebagai fokus utama dalam novel yang dikaitkan dengan posisi mereka sebagai seorang zainichi Korea.

Oleh karena itu, penelitian yang akan dilakukan ini hendak mengkaji representasi generasi pertama hingga ketiga zainichi Korea di dalam novel ini yang mendapatkan diskriminasi dan juga mengalami krisis identitas akibat perlakuan tidak setara yang mereka dapatkan dalam masyarakat dengan mengaitkannya dengan bisnis pachinko yang menjadi fokus utama. Selain itu, penelitian ini juga akan menjawab mengapa pachinko dianggap begitu penting dalam novel ini sehingga harus diangkat menjadi fokus utama, bahkan menjadi satu bagian penting dalam cerita.

\section{Pluralis dalam Sosok Generasi Pertama Zainichi}

Dalam sejarah, perkembangan para pendatang di Korea memang dimulai dari distrik Ikaino di Osaka pada 1923. Dikatakan pula para pendatang Korea banyak tinggal di daerah itu karena banyaknya pabrik kecil dan juga menengah yang berkembang di sana. Di sanalah mereka banyak mencari nafkah. Mayoritas para pendatang Korea berasal dari Pulau Jeju, yang hampir sebagian besar penduduknya bermigrasi ke Jepang hingga tahun 1934 (Wender, 2005). Dalam novel Pachinko inilah kawasan Ikaino ini menjadi tempat dimulainya cerita kehidupan generasi pertama zainichi di Osaka. Sunja sebagai representasi tokoh generasi pertama dalam novel ini dapat dilihat sebagai tokoh yang mencerminkan posisi sebagai zainichi generasi pertama, yaitu sekolompok masyarakat etnis terabaikan yang 
mulai menetap di Jepang. Di sini mereka banyak menerima tekanan sosial dari masyarakat di lingkungannya.

Di dalam kisah Sunja, dapat diketahui situasi dan perlakuan merendahkan yang dilakukan masyarakat Jepang terhadap etnis minoritas zainichi Korea pada periode awal dalam novel ini. Orang Korea yang tinggal di daerah tempat tinggalnya sama-sama berada dalam kondisi yang tidak layak sehingga mereka harus mencuri untuk mencari sesuap nasi. Sunja diwanti-wanti oleh kakak iparnya untuk tidak memberi makanan kepada orang Korea di sekitar mereka karena hal ini membuat mereka berpikir bahwa keluarga Sunja kaya sehingga mereka mencuri di setiap ada kesempatan (Lee, 2017: 114-115). Kondisi ini mencerminkan fakta sejarah ketika orangorang Korea ditarik untuk bekerja di Jepang tidak mendapatkan kehidupan dan pekerjaan yang layak. Tempat tinggal mereka seringkali tidak layak karena mereka terpaksa harus hidup bersama hewan peliharaan. Kondisi inilah yang membuat mereka dikucilkan dari masyarakat karena dianggap sebagai pemabuk, pencuri, orang miskin yang tinggal bersama babi, dan lain sebagainya.

Kebencian orang Jepang terhadap orang Korea terpupuk dari pemikiran imperialis Jepang (Osborn, 2015: 8). Pemikiran inilah yang masih membuat masyarakat Jepang memandang bahwa masyarakat Korea adalah etnis yang subordinat dan marjinal. Seberapa tinggi status sosial mereka maupun seberapa tinggi pendidikan yang mereka dapatkan, posisi masyarakat Korea di Jepang pada masa itu masih sama rendahnya dengan masyara- kat kelas bawah. Hal inilah yang memengaruhi perlakuan masyarakat Jepang terhadap masyarakat Korea, terutama dengan mengucilkan mereka dari masyarakat. Namun, hal ini justru menumbuhkan sensitivitas terkait gerakan separatis dan perlawanan terhadap kekaisaran Jepang sehingga justru memunculkan stigma masyarakat Jepang kepada zainichi yang dianggap memiliki tendensi pemberontak sehingga gerakan masyarakat Korea sangat dikekang dan diawasi. Orang Korea dianggap sebagai mereka yang terlahir sebagai pembuat onar terutama mereka yang memiliki inteligensi tinggi.

Generasi pertama zainichi berusaha berasimilasi atau bahkan memisahkan diri dengan lingkungan yang ada. Beberapa mencapai mobilitas sosial ekonomi meskipun harus dikucilkan dari masyarakat umum. Karena diskriminasi, perbedaaan bahasa, dan kurangnya pendidikan, satu-satunya pekerjaan yang tersedia bagi kebanyakan orang Korea adalah pekerjaan yang disebut "Tiga D" (dangerous, demanding, dan dirty). Masyarakat Korea, terutama di Osaka, sering mendapat pekerjaan di pabrik-pabrik kaca, pemintalan kain, dan karet. Mereka juga bekerja di tambang batubara dan pembangunan kanal (Lee, 2012: 4). Keadaan ini pula yang tidak luput digambarkan dalam novel Pachinko melalui representasi generasi pertama zainichi dalam novel. Kakak ipar Sunja harus bekerja di pabrik dengan upah rendah sehingga membuatnya harus bekerja di tempat lain untuk memberikan tambahan penghasilan bagi keluarganya. Kondisi ini memaksa Sunja dan istri kakak iparnya, yaitu Kyunghee, untuk mencari nafkah tambahan dengan berjualan 
kimchi atau makanan lainnya. Pada akhirnya, dengan bantuan Koh Hansu yang di awal cerita pernah menjalin hubungan dengan Sunja, Sunja dan Kyunghee dapat bekerja di salah satu restoran di Osaka sebagai juru masak. Pekerjaan di bidang pelayanan makanan inilah yang membuktikan bahwa tidak ada tempat bagi generasi pertama zainichi di dalam masyarakat dalam novel Pachinko. Keadaan ini tidak jauh berbeda dengan fakta historis tentang pengucilan etnis Korea di dalam masyarakat Jepang.

Dengan diskriminasi yang mereka dapatkan, generasi pertama zainichi dalam novel ini, yang direpresentasikan oleh tokoh Sunja, tetap berusaha untuk bertahan hidup di tengah masyarakat. Identitas pluralis zainichi yang tidak melakukan naturalisasi dan tetap mempertahankan identitas asli mereka sebagai seorang Korea terepresentasi dalam sikap Sunja. Hal ini juga disebabkan pada rentang waktu tersebut Korea masih berada di bawah penjajahan Jepang dan belum ada perjanjian yang memberikan hak untuk naturalisasi bagi pendatang dari Korea. Sebagai salah satu sistem, pemerintah Jepang memaksa mereka untuk menggunakan nama Jepang. Mereka pun diharuskan mengubah nama menjadi 'Boku', yaitu sebagai pelafalan Jepang dari 'Baek’.

Namun, sebagai zainichi, keluarga Sunja tidak memilih menggunakan nama Jepang mereka, yaitu 'Bando', tetapi lebih banyak menggunakan 'Boku' sebagai bentuk sikap mereka yang tetap memegang teguh etnis asal mereka. Selain itu, Sunja digambarkan tetap memegang teguh prinsip sebagai seorang Korea "selalu merindukan ritual jesa (penghormatan pada leluhur)" (Lee, 2017: 526). Meski Sunja yang mengikuti keluarga Baek Isak telah menjadi seorang Kristian dan telah lama meninggalkan Korea dan kepercayaannya, pelaksanaan budaya bukanlah suatu kewajiban, tetapi hal tersebut menjadi suatu pengobat rindu baginya karena telah lama meninggalkan Korea. Generasi pertama dalam novel ini direpresentasikan sebagai mereka yang tidak membuang identitas asli mereka seberapa pun besarnya diskriminasi yang mereka harus hadapi karena hal itu adalah satu -satunya cara untuk mengenang kampung halaman mereka.

\section{Asimilasionis Zainichi dan Pachinko: Potret Generasi Kedua Zainichi dalam Novel Pa- chinko}

Generasi kedua zainichi adalah masyarakat yang mendapatkan pengucilan dari masyarakat umum dengan status sosial rendah yang hakhaknya masih tidak setara dengan larangan dalam berpartisipasi dengan masyarakat umum meski mereka terlahir dan besar di Jepang (Lee, 2012: 3). Tokoh Noa, yang merupakan anak Sunja dan Koh Hansu yang dibesarkan oleh Sunja dan suaminya, Baek Isak, lahir di Osaka pada sekitar tahun 1933. Ia dideskripsikan sebagai seorang anak yang tumbuh dan besar di Ikaino dan bersekolah dengan anak-anak Jepang dan sebagian kecil anak Korea lainnya. Noa memiliki nama Korea yang disesuaikan dengan pelafalan Jepang, yaitu "Boku" dan nama keluarga Jepang (tsumei), yaitu "Bando". Hal ini dilakukan "untuk menghindari diskriminasi, dalam hal ini yaitu untuk mendapatkan 
tempat tinggal, pekerjaan, dan lain sebagainya" (Harajiri, 2003; Hyun dalam Aoki, 2012: 378).

Noa tumbuh menjadi anak Korea yang "berbeda dengan anak ghetto Korea lainnya di lingkungan mereka, ia terlihat seperti anak kalangan menengah Jepang" (Lee, 2017: 194). Bahkan ia memiliki kemampuan belajar di atas rata-rata sehingga menjadikannya murid yang pintar, jauh berbeda dengan anak -anak Korea seusianya.

Like all children, Noa kept secrets, but his were not ordinary ones. At school, he went by his Japanese name, Nobuo Boku, rather than Noa Baek; and though everyone in his class knew he was Korean from his Japanized surname, if he met anyone who didn't know this fact, Noa wasn't forthcoming about this detail. He spoke and wrote better Japanese than most native children.

"Above all the other secrets that Noa could not speak of, the boy wanted to be Japanese; it was his dream to leave Ikaino and never to return" (Lee, 2017: 195).

Pandangan orang Jepang terhadap imigran dari Korea pada masa itu sangatlah negatif dan inilah yang juga dialami oleh Noa di sekolah. Dideskripsikan bahwa Noa harus menerima perlakuan yang tidak setara oleh anak-anak Jepang dan bahkan gurunya sendiri (Lee, 2017: 195). Seperti anak Korea lainnya, ia harus rela menerima ejekan, termasuk nama panggilan terhadapnya. Noa yang sudah terbiasa diejek dan diolok seperti teman-teman Korea lainnya harus menanggung ejekan lain berupa nama panggilan buruk yang ditujukan padanya, yaitu "kotoran bawang" (Lee, 2017: 194) akibat bau bumbu kimchi yang menempel di bajunya. Hal ini menunjukkan bahwa diskriminasi juga diterima oleh para pendatang dari
Korea, bahkan sejak masih kanak-kanak, akibat latar belakang mereka.

Secara nonverbal pun, Noa dan anak Korea sebaya di sekolahnya mendapatkan diskriminasi yang menumbuhkan ketidaksukaannya terhadap lingkungan sekolahnya. Dalam novel disebutkan bahwa "anak-anak Jepang yang pintar di sekolahnya dan yang ia kagumi, tidak sudi melihat dan berbicara dengannya" (Lee, 2017: 214). Secara nonverbal, diskiriminasi ini membuat Noa menumbuhkan rasa penolakan terhadap identitas etnisnya sebagai orang Korea. Noa ingin dapat berinteraksi dengan normal di sekolah dan ini tidak didapatkannya karena identitas etnisnya. Inilah yang membuat Noa mencoba tidak memperlihatkan identitasnya secara terbuka seperti yang dipaparkan dalam kutipan di atas bahwa identitas Koreanya merupakan "rahasia besarnya".

Latar belakang yang ia miliki sebagai zainichi Korea menumbuhkan tekad kuat Noa untuk belajar dan juga bekerja lebih keras untuk mendapatkan kesetaraan dalam status sosial yang ia impikan agar ia merasakan kehidupan normal yang ia inginkan. Sejak kecil, Noa berharap bisa keluar dari kondisi masyarakat terpinggirkan yang tidak pernah mendapatkan kesempatan yang baik di masyarakat. Mimpinya adalah untuk dapat menjadi seorang "Jepang" yang bisa meninggalkan tempat kelahirannya, yaitu Ikaino dan tidak pernah kembali lagi. Noa belajar keras untuk melampaui teman-teman sebayanya seperti dalam kutipan di atas. Ia belajar dengan baik, bertingkah laku baik, dan tidak terlalu banyak berinteraksi dengan anak Korea sebaya di daerah lingkungannya. Bahkan, ketika umurnya beranjak 
remaja dan ia harus mempersiapkan ujian masuk universitas, Noa berjuang keras untuk bisa diterima di Universitas Waseda, yang pada akhirnya terwujud pada sekitar tahun 1960 (Lee, 2017: 304).

Di Universitas Waseda, Tokyo, Noa tetap menutup dirinya dari sekitar dan tidak membuka identitasnya sebagai seorang Korea, karena ia paham bahwa orang Jepang tidak mau berinteraksi dengan orang Korea seperti dirinya. Hal ini memperlihatkan bahwa terdapat krisis identitas yang dirasakannya. Krisis identitas yang ia alami diperparah dengan fakta bahwa seorang yakuza Korea yang sukses di black market Jepang, yaitu Koh Hansu, adalah ayah biologisnya. Noa merasa bahwa darah Korea yang dibawanya diperparah dengan darah yakuza yang berasal dari Hansu dan tidak ada hal yang bisa memperbaiki hal tersebut.

Karena hal ini, di dalam novel dipaparkan bahwa Noa merasa "terkutuk" (Lee, 2017: 423) dan berpikir bahwa lebih baik apabila ia tidak pernah lahir sama sekali. Stereotip akan orang Korea yang negatif, yang harus ia hadapi sepanjang hidupnya diperparah dengan fakta adanya darah kriminal yang mengalir dalam dirinya. Merasa malu, Noa pun meninggalkan seluruh keluarganya dan pergi ke tempat yang keluarga dan bahkan Hansu pun tidak dapat menemuinya sampai selama enam belas tahun, yaitu kota Nagano. Di dalam suratnya ia mengatakan bahwa "ia tidak akan kembali lagi" (Lee, 2017: 348) dan ia pun berhenti melanjutkan studinya di Tokyo. Noa menetap di kota Nagano dengan membuang segala masa lalunya, termasuk identi- tasnya sebagai seorang Korea dan mengganti nama keluarga Jepangnya, "Bando" menjadi "Ban", agar tidak terlihat bahwa ia adalah seorang Korea. Pada awal pertama ia datang di Nagano pun, teman pertama yang menawarkan pekerjaan padanya mengira bahwa ia adalah seorang "Jepang". Selama enam belas tahun Noa menetap dan pada akhirnya memiliki keluarga di sana, ia sangat berhati-hati untuk tidak berlaku seperti orang Korea dan tidak pernah berhubungan dengan keluarganya, kecuali mengirimkan uang kepada ibunya. Selama itu pulalah tidak ada satu orang pun, termasuk istri, keempat anak, mertuanya yang mengetahui identitas aslinya.

"No one knows I'm Korean. Not one person"
"My wife doesn't know. Her mother would never
tolerate it. My own children don't know, and I will not
tell them. My boss would fire me. He doesn't employ
foreigners. Umma, no one can know..."
"Is it so terrible to be Korean?"
"It is terrible to be me."
(Lee, 2017: 424).

Berdasarkan kutipan di atas, dapat diketahui bahwa Noa telah melakukan naturalisasi, yaitu berganti kewarganegaraan menjadi warga Negara Jepang. Pada tahun 1965, Jepang dan Korea Selatan manandatangani Normalisation Treaty yang berisi perizinan zainichi Korea untuk mendapatkan status warga negara permanen di Jepang. Kebijakan ini diperuntukan bagi mereka yang memiliki kewarganegaraan Korea Selatan dan tinggal secara terus menerus di Jepang sejak sebelum perang berakhir (Wickstrum, 2016: 47). Sikap Noa yang sejak kecil cenderung ingin menjadi seorang Jepang tulen dan pada akhirnya melakukan naturalisasi untuk mendapatkan warga negara permanen Jepang membuatnya termasuk ke dalam 
identitas zainichi Korea yang asimilasionis seperti yang disebutkan oleh Fukuoka dan Tsujiyama (1991). Meninggalkan rumah dan keluarganya tanpa bertemu selama 16 tahun lamanya menjadi salah satu bukti sikap asimilasionis dalam diri Noa yang berarti membuang etnisnya sebagai orang Korea. Sikapnya yang tidak jujur tentang etnis aslinya ditunjukkan dalam kehati-hatiannya menjaga rahasia tersebut dari orang-orang di tempat tinggalnya yang baru, bahkan dari istri dan anak-anaknya.

Sikap asimilasionis dalam diri Noa tersebut dimulai dari perlakuan yang ia dapatkan sejak kecil, yaitu pengalaman yang membuatnya tidak mendapatkan perlakuan yang tidak baik dari teman-teman dan gurunya. Perlakuan inilah yang membuatnya bermimpi untuk pergi dari Ikaino, tempat tinggalnya sebagai ghetto Korea, dan hidup secara normal. Harapan ini juga dapat diartikan sebagai keinginannya untuk meninggalkan asal-usulnya sebagai seorang Korea dan mendapatkan kewarganegaraan Jepang untuk dapat mendapatkan hak yang sama di masyarakat. Pada akhirnya, Noa berhasil mewujudkan harapannya untuk hidup normal sebagai orang Jepang dan mendapatkan perlakuan yang baik meskipun harus meninggalkan keluarganya dan identitas aslinya.

Namun demikian, krisis identitas yang Noa alami masih dapat ditemukan. Krisis identitas ini justru memuncak sesaat setelah Noa akhirnya bertemu dengan ibunya, Sunja, setelah 16 tahun berpisah. Khawatir orangorang di tempatnya menetap akan menge- tahui jati dirinya sebagai seorang Korea, ia pun mengakhiri hidupnya dengan menembak dirinya sendiri. Nasib tragis Noa ini menunjukkan sikapnya yang begitu asimilasionis, yang bertekad untuk tidak lagi mengingat asal usulnya dan seberapa besar krisis identitas yang dihadapinya. Sikap ini juga menunjukkan bahwa Noa tidak dapat mencari jalan keluar tentang statusnya di Jepang apabila ia menjalin kembali hubungan dengan keluarga Koreanya yang telah terputus. Melalui tokoh Noa dapat diketahui bahwa sehormat dan setinggi apa pun pendidikan seorang zainichi Korea, sampai sekitar tahun 1970 nasib mereka masih belum pasti, terutama mengenai kesetaraan status sosial di dalam masyarakat hegemoni Jepang pada saat itu.

Betapa pun sukses dan normalnya kehidupan Noa yang akhirnya menjadi warga negara Jepang, ada fakta ironis yang dapat terlihat jelas. Di tempat barunya, Noa mendapatkan pekerjaan sebagai karyawan perusahaan pachinko terkenal di Nagano. Chan (2018) menyebutkan bahwa bisnis pachinko adalah bisnis judi yang cukup dikenal di Jepang dan dapat dianggap sebagai bisnis yang vulgar, tidak bersih dan berbahaya. Menurut Lee (dalam Chan, 2018), secara historis bisnis pachinko dimulai dan didominasi oleh pendatang dari Korea dan keturunannya di masa setelah Perang Dunia II berakhir. Kebanyakan pendatang Korea terpaksa masuk ke dunia perjudian dan pelayanan makanan karena tidak banyak orang yang mau mempekerjakan orang Korea di bidang lain. Bagi seorang murid teladan dan orang yang jauh dari citraan orang Korea yang tidak baik di mata orang Jepang, Noa pantas 
dan layak mendapatkan pekerjaan terhormat seperti orang Jepang. Akan tetapi, setinggi apa pun pendidikan Noa, bisnis pachinko inilah yang menjadi labuhan terakhirnya dalam mencari pekerjaan. Meskipun Noa hanya bekerja di bagian manajemen kantor, ia tetap berada di lingkungan bisnis pachinko yang dipandang sebelah mata oleh masyarakat Jepang kala itu.

\section{Pluralis Zainichi dan Pachinko: Potret} Generasi Kedua Zainichi dalam Novel Pachinko

Seperti yang dialami Noa, adik berbeda ayahnya, yaitu Mozasu, juga mengalami diskriminasi saat masih bersekolah. Mozasu harus bertahan dengan cacian dan ejekan yang dilontarkan oleh guru dan anak-anak Jepang sebayanya di sekolah. Ketika berusia 13 tahun, Mozasu menyamakan sekolah sebagai "neraka" karena ia harus berada di kelas anak -anak usia 10 tahun akibat kurangnya kemampuan akademiknya. Panggilan dari guru Mozasu, yaitu "Si bodoh Korea" untuknya membuatnya tidak sabar untuk segera meninggalkan "neraka"nya (Lee, 2017: 267).

The Japanese kids would have nothing to do with him, but Mozasu no longer gave a shit. When he was younger, getting picked on used to bother him, though far less that it had bothered Noa, who had compensated by outperforming his classmates academically and athletically. Every day, before school began and after school ended, the bigger boys told Mozasu, "Go back to Korea, you smelly bastard. If there was a crowd of them, Mozasu would keep walking; however, if there were only one or two assholes, he would hit them as hard as he could until he saw blood (Lee, 2017: 269).

Cemoohan dan perlakuan yang selalu ia terima di "neraka"nya, seperti ejekan "kembalilah ke Korea, dasar orang Korea bau" tidak membuat Mozasu menggunakan nama Jepangnya, yaitu "Bando", yang tertulis dalam semua dokumen resminya. Mozasu menggunakan nama Korea yang disesuaikan dengan pelafalan Jepang, yaitu "Mozasu Boku". Berbeda dengan Noa yang berusaha untuk menutupi identitas Koreanya, Mozasu seakan tidak terlalu menghiraukannya. Penggunaan nama Jepang untuk zainichi Korea membuat mereka tidak terlihat secara signifikan di Jepang. Akan tetapi, dalam waktu yang bersamaan, dengan tetap menggunakan nama Korea yang dilafalkan dalam bahasa Jepang mereka dalam dokumen-dokumen resmi, membuat mereka tetap menjadi "orang lain" atau "alien" di masyarakat Jepang yang sangat dominan (Aoki, 2012: 378). Meskipun dianggap "orang lain", Mozasu tidak memiliki keinginan untuk melakukan naturalisasi, yaitu mengganti kewarganegaraannya menjadi orang Jepang.

Dengan diskriminasi yang diterima oleh zainichi Korea, mereka tidak mendapatkan pekerjaan yang layak. Hal ini pulalah yang terjadi pada Mozasu sebagai orang Korea yang sulit dalam mencari pekerjaan. Sifatnya yang cukup temperamental membuatnya berurusan dengan polisi, yang justru membuatnya mendapatkan pekerjaan sebagai pegawai di perusahaan pachinko milik seorang Korea bernama Goro. Tidak semua orang di balik usaha pachinko merupakan orang jahat dan tidak bertanggung jawab. Di dalam novel Pachinko, Mozasu dideskripsikan sebagai orang yang jujur dan bertanggung jawab. Mozasu selalu memberikan gaji yang didapatkannya kepada ibunya. Dari uang tersebut ibunya akan memberikan uang saku untuk Mozasu. 
Bisnis pachinko inilah yang menjadi titik balik berubahnya keadaan keluarganya. Bukan hanya menjadi karyawan Goro, bertahun-tahun setelah bekerja bersama Goro, Mozasu dapat membuka usaha pachinkonya sendiri. Dengan kekayaan yang dimiliki olehnya, ia dapat membuat pesta mewah demi merayakan hari lahir anaknya, Solomon, menyekolahkannya hingga ke Amerika, dan memberikan pakaian-pakaian mewah serta perhiasan mahal untuk kekasihnya, Etsuko. Sampai akhir novel dijabarkan bahwa Mozasu menjadi seorang yang sukses dalam bisnis tersebut. Kesuksesan yang diraihnya tidak dilakukan dengan hal-hal yang "tidak bersih" atau tidak jujur, seperti apa yang pada umumnya dipikirkan orang-orang terutama orang Jepang. Mozasu bekerja dengan jujur dan rajin membayar pajak (Lee, 2017: 525).

Di dalam novel disebutkan bahwa Mozasu sangat sukses dalam bisnis pachinko yang ia kelola sehingga tidak perlu lagi bersusah payah untuk mencari nafkah seperti apa yang ibunya lakukan sebagai generasi pertama zainichi. Akan tetapi, kesuksesan yang didapatnya tidak membuatnya lepas dari krisis identitas yang dialaminya, seperti yang dipaparkan dalam kutipan berikut:

"Listen, man, there's nothing you can do. This country isn't going to change. Koreans like me can't leave. Where we gonna go? But the Koreans back home aren't changing, either. In Seoul, people like me get called Japanese bastards, and in Japan, I'm just another dirty Korean no matter how much money I make or how nice I am. So what the fuck? All those people who went back to the North are starving to death or scared shitless." (Lee, 2017).

Berkebalikan dengan status sosial sebagai seseorang yang melakukan naturalisasi seperti tokoh Noa, status masyarakat yang tidak melakukan naturalisasi dan masih memiliki kewarganegaraan Korea Selatan, seperti tokoh Mozasu, masih ambigu. Zainichi Korea terus menjadi "alien" atau orang terpinggirkan yang dikontrol di bawah hukum imigrasi Jepang. Mereka akan terus menjadi warga negara asing, kecuali mereka mau melakukan naturalisasi dan menjadi warga Negara Jepang (Wickstrum, 2016: 47). Status inilah yang tidak memberikan banyak kemudahan dalam keseharian mereka.

Mozasu menekankan pemikirannya tentang Jepang bahwa hingga kapan pun Jepang tidak akan berubah. Meskipun sudah berpuluh tahun berlalu setelah Korea bebas dari penjajahan Jepang, Jepang tetap tidak memberikan kemudahan akses bagi para pendatang Korea yang telah menetap di sana. Dalam kutipan ini, Mozasu dideskripsikan mengalami krisis identitas berdasarkan pernyataan bahwa tidak ada tempat lagi untuk orang Korea sepertinya. Mozasu tetap tidak dapat kembali ke Korea karena secara hukum pada masa itu mereka belum dapat dengan bebas pergi ke luar negeri.

Namun, apabila mereka diberi kesempatan untuk pulang pun, dalam keadaan mereka tidak lahir dan besar di Korea, akan membuat mereka tidak mengerti sepenuhnya tentang akar etnisnya. Selain itu, keadaan Korea yang belum stabil ketika itu juga akan membuatnya tidak jauh berbeda seperti ketika masa awal keluarganya bermigrasi. Apabila para pendatang ini kembali ke Korea, mereka akan menjadi seperti orang asing dan belum tentu mendapat kehidupan yang lebih baik dan layak. Hal inilah yang menjadi alasan Mozasu yang berpikir bah- 
wa di sana mereka akan dianggap "bajingan" Jepang karena pada kenyataannya mereka lahir dan besar di Jepang dan sudah sepenuhnya seperti orang Jepang.

Sementara di tempat kelahiran mereka, yaitu di Jepang, para pendatang ini tetaplah orang asing, yang masih memiliki stereotip yang kurang baik seperti yang terungkap dalam kutipan di atas. Meskipun tidak banyak yang masih berada dalam kemiskinan yang membuat mereka dianggap kotor, mereka tetap tidak bisa melepaskan pandangan "kotor" terhadap para imigran dari Korea. Bisnis pachinko yang memang tidak jarang dianggap sebagai bisnis "kotor" inilah yang membuat mayoritas para pendatang Korea mendapatkan pekerjaan dan bahkan kesuksesan sehingga stereotip ini masih melekat seberapa pun sukses dan kaya mereka itu. Apabila ada pendatang Korea di Jepang yang kaya dan memiliki kehidupan yang sukses, mereka diasosiasikan pada bisnisbisnis yang biasa dilakukan para gangster atau yakuza, salah satunya adalah bisnis pachinko. Hal ini dapat dibuktikan dari katakata Mozasu yang ia katakan kepada seorang tokoh Jepang bernama Etsuko yang menjadi kekasihnya beberapa tahun setelah istrinya meninggal dunia bahwa ia adalah "yakuza pachinko" (Lee, 2017: 433).

Pemikiran Mozasu tentang "semua orang berpikir bahwa orang Korea adalah gangster" (Lee, 2017: 433) merupakan cerminan dari pandangannya mengenai status etnisnya sendiri di dalam masyarakat. Melalui tokoh Mozasu, para pendatang dari Korea di Jepang kala itu masih berada dalam ketidaksetaraan dalam masyarakat meskipun Jepang sudah tidak lagi berkuasa atas negara mereka. Para zainichi masih harus menerima kenyataan bahwa belum ada tempat yang akan menerima mereka dengan normal dan setara seperti layaknya masyarakat pada umumnya tanpa ada stereotip yang melekat. Kesuksesan yang didapat dengan cara yang menurut mereka bersih pun tetap dianggap sebelah mata dan mereka yang kaya akan tetap menjadi orang Korea yang "kotor".

Fakta bahwa tokoh Mozasu tidak melakukan naturalisasi menjadi kewarganegaraan Jepang dan tetap hidup di tengah masyarakat Jepang dengan menggunakan nama Koreanya, menunjukkan karakteristik identitas zainichi yang pluralis. Para pluralis ini lebih cenderung tidak menolak identitas mereka dan menekankan pentingnya hidup bersama masyarakat Jepang. Di sekitarnya, Mozasu memiliki beberapa teman Jepang yang dekat dengannya seperti teman masa remajanya yang bernama Haruki dan juga kekasihnya, Etsuko. Mozasu tidak merasa malu dengan identitasnya sebagai seorang Korea dan tidak berusaha menutupi etnisnya tersebut.

Meskipun sedikit karakter individualis zainichi Korea yang berfokus pada kesuksesan sosial ekonomi, yang terlihat dari kerja keras Mozasu dalam bisnis pachinkonya, aspek pluralis lebih mendominasi sikapnya. Hal itu disebabkan individualis zainichi lebih tidak acuh mengenai identitas mereka sebagai seorang zainichi, kehidupan politik etnisnya, dan lain sebagainya. Meskipun Mozasu tidak memilih jalan naturalisasi, bukan berarti ia tidak acuh pada identitas mereka. Dia tetap merasa ada ketidakadilan, terutama akibat ketidaksetaraan atau diskrimi- 
nasi yang didapatnya sebagai seorang zainichi. Sikap ini terlihat dalam beberapa kutipan di atas, yaitu ketika Mozasu membela diri saat ia dicemooh oleh teman-temannya. Ketika suatu waktu ia akan mengantar anaknya untuk mendapat kartu warga asing atau alien card, sikap sinis terhadap hal itu pun menunjukkan bahwa ia peduli akan status sosialnya di masyarakat Jepang.

\section{Generasi Ketiga Zainichi dan Pachinko}

Zainichi Korea generasi ketiga adalah mereka yang lahir di Jepang dan tumbuh seperti orang Jepang pada umumnya hingga hampir tidak bisa dibedakan dengan orang Jepang, yang mengalami asimilasi, baik secara sukarela maupun dengan terpaksa. Beberapa di antara mereka masih berjuang mempertahankan identitasnya sebagai orang Korea, sementara sisanya berjuang mengklaim kewarganegaraan Jepang yang tidak diberikan secara cuma-cuma. Tei (dalam Morooka, 2016: 4) mengemukakan bahwa zainichi Korea memililiki hubungan kontradiktif antara situasi formal mereka di mata hukum sebagai warga negara Korea dan kondisi budaya mereka sebagai warga Jepang. Hal ini menjadi semakin sulit bagi mereka yang tumbuh dewasa pada tahun sekitar tahun 1980, karena zainichi Korea memiliki cara hidup yang sama persis seperti orang Jepang dan memiliki hak yang hampir serupa di mata hukum. Oleh sebab itu, beberapa dari mereka hanya mengidentifikasi diri sebagai seorang Korea di atas kertas, selebihnya mereka merasa diri mereka adalah bagian dari Jepang.
Zainichi generasi ketiga dalam novel $\mathrm{Pa}$ chinko direpresentasikan oleh tokoh Solomon, yaitu anak Mozasu. Solomon masih mengalami tindak permarginalan meskipun lahir dan besar di Jepang. Hukum zainichi Korea yang tinggal di Jepang dianggap sebagai seorang 'tamu' ditetapkan sejak 1947. Tanaka (dalam Wickstrum, 2016: 45) mengemukakan bahwa pada tahun 1947, semua orang Korea di Jepang tunduk pada Hukum Pendaftaran Orang Asing (Alien Registration Law), yang telah disetujui oleh Panglima Tertinggi Sekutu yang menyatakan bahwa orang Taiwan dan Korea yang berada di Jepang akan dianggap sebagai tamu asing dan wajib membawa kartu pendaftaran orang asing (alien registration card) bersama mereka setiap saat. Solomon yang lahir pada 1965 pun harus menaati hukum tersebut.

They were going to pick up Solomon at his school to take him to get his alien registration card. Koreans born in Japan after 1952 had to report to their local ward office on their fourteenth birthday to request permission to stay in Japan. Every three years, Solomon would have to do this again unless he left Japan for good (Lee, 2017: 437).

Adanya hukum ini secara tidak langsung mengarah pada fakta bahwa pemerintah Jepang memiliki kuasa atas mereka yang dianggap 'tamu asing' di atas tanah Jepang. Bahkan, tokoh Mozasu menyamakan kartu orang asing yang harus mereka miliki dengan sebutan label yang biasa dipakai di leher anjing. Hal ini menjadi simbol bahwa hukum ini cukup mengekang bagi zainichi Korea. Mereka yang berkebangsaan Korea dianggap sebagai orang asing, terlepas dari fakta bahwa mereka lahir, tumbuh besar, dan bahkan fasih berbahasa Jepang. Mozasu dan Solomon lahir dan tumbuh besar di Jepang, tetapi di mata hukum Jepang mereka 
tetap dianggap sebagai zainichi Korea dan diperlakukan tidak adil. Perlakuan tidak adil dari segi penerapan hukum, sampai cemoohan bernada etnis selalu mereka terima di manapun mereka berada.

"I was fired," Solomon said.

"Nani?" the three men said at once. "For what?"

"Kazu said that the client is holding off on deal. They don't need me anymore. He said that if there was an investigation because of-" Solomon stopped himself before saying the word "yakuza," because suddenly, he wasn't sure. His father wouldn't have associated with criminals" (Lee, 2017: 515).

Solomon yang sudah belajar ekonomi di Amerika bahkan tidak bisa mendapatkan pekerjaan yang layak sesuai dengan kemampuannya. Meskipun ia sudah mendapatkan posisi yang baik di perusahaan tempatnya bekerja, identitasnya sebagai orang Korea, terlebih statusnya sebagai anak seorang pebisnis pachinko, membuatnya kehilangan pekerjaan prestisnya. Sekalipun mendapat pekerjaan yang lebih mengandalkan keterampilan daripada tenaga, zainichi Korea cenderung tidak dipercaya sepenuhnya dan dijadikan kambing hitam ketika ada masalah. Tidak jarang, kelompok zainichi Korea dikaitkan dengan keberadaan "yakuza".

Pencarian jati diri zainichi Korea generasi ketiga dihadapkan pada pilihan yang cukup rumit: menaturalisasi diri dan menjadi "Jepang" di mata hukum meskipun menerima pemarginalan di tengah-tengah masyarakat, menjadi seorang nasionalis seutuhnya dengan tetap merasa asing dengan budayanya sendiri, atau bersikap sebagai individu tanpa terikat dengan salah satu etnis. Tokoh Solomon menunjukkan tanda- tanda zainichi individualis pada awalnya. Ia tidak peduli urusan kewarganegaraan Jepang atau Korea, bahkan tidak memberontak saat diminta mengurus dokumen kewarganegaraan yang berlaku sesuai hukum. Solomon tidak menunjukkan tanda-tanda perlawanan sama sekali. Ia juga memberanikan diri untuk mencari pekerjaan di luar sterotip pekerjaan zainichi Korea pada umumnya. Pola pikirnya dipengaruhi oleh latar belakang pendidikannya. Ia cenderung fokus pada tujuan-tujuan hidupnya dan tidak ambil pusing dengan pandangan masyarakat.

Namun, seiring berjalannya cerita, semakin banyak bukti yang menunjukkan Solomon sebagai seorang pluralis dibandingkan individualis. Solomon tidak ikut terseret arus dalam perkataan Hana, anak dari Etsuko, yang mencemooh Jepang. Solomon mencoba untuk bersikap objektif, tetapi dengan terus menampik fakta-fakta tentang kesemena-menaan Jepang sehingga secara tidak langsung ia membela Jepang dengan membela bosnya yang bernama Kazu.

Hal serupa juga muncul saat Solomon dan Phoebe, kekasihnya, bersitegang. Phoebe merasa Solomon tidak sadar dirinya sedang diremehkan oleh bosnya, Kazu. Namun, ketika Phoebe mengutarakan hal tersebut pada Solomon, Solomon justru menganggap Phoebe berlebihan dan menjadi bias hanya karena Kazu orang Jepang. Padahal, faktanya, Solomon memang masih memiliki ciri "Korea" di mata Kazu. Keputusan Solomon dan Phoebe untuk berpisah juga diwarnai kebiasan terhadap Jepang. Pendapat keduanya yang tidak setara akan Jepang membuat Solomon menjadi eng- 
gan menikah dengan Phoebe. Menurutnya, Phoebe menjadi egois. Bahkan, meskipun dengan menikahi Phoebe berarti Solomon bisa mendapatkan kewarganegaraan utuh sebagai seorang Amerika, ia enggan membayar keputusan tersebut dengan meninggalkan Jepang. Solomon merasa keputusan untuk meninggalkan Jepang menjadi sebatas angan-angan yang ditanamkan oleh ayahnya, sementara dirinya sendiri kini enggan.

... he realized that he didn't want to become an American. It made sense for him to do so; it would have made his father happy. Was it better to be American than a Japanese? He knew Koreans who had become naturalized Japanese, and it made sense to do so, but he didn't want to do that now, either. Maybe one day. She was right; it was weird that he was born in Japan and had a South Korean passport. He couldn't rule out getting naturalized. Maybe another Korean wouldn't understand that, but he didn't care anymore.

"No. I can't marry her. And I told her that I'd rather live in Japan. Work in pachinko." (Lee, 2017: 524).

Dalam kutipan di atas dapat diketahui bahwa Solomon memutuskan untuk terjun ke dunia pachinko. Solomon merasa pachinko adalah takdir yang layak untuk ia jalani. Pachinko menjadi "solusi" di bidang pekerjaan bagi para zainichi Korea. Dalam bisnis yang dianggap sebelah mata inilah, zainichi Korea justru sukses. Mereka yang cukup profesional berkecimpung di dunia pachinko bisa dikatakan sebagai pebisnis hebat, terlepas dari pandangan tentang pekerjaan tersebut di mata masyarakat. Pachinko rata-rata didominasi oleh zainichi Korea dan pada tahun 1990-an, sekitar 70-80\% bisnis pachinko dimiliki oleh zainichi Korea (Morooka, 2016: 10). Pada awalnya, Solomon tidak tertarik untuk bergabung dalam bisnis pachinko milik ayahnya. Akan tetapi, setelah kejadian pemecatan sepihak oleh Kazu dan argumenargumen Hana dan Phoebe yang mencemooh Jepang sudah tidak relevan lagi dengan pemikirannya, Solomon menjadi bimbang pada keputusan awalnya yang menganggap hidup di Amerika adalah solusi untuk kemalangannya di Jepang.

\section{Simpulan}

Novel Pachinko memaparkan kehidupan generasi pertama hingga ketiga zainichi Korea menghadapi diskriminasi dan perlakuan yang tidak setara di Jepang. Generasi pertama yang direpresentasikan oleh Sunja sebagai generasi awal pembuka garis keturunan pendatang Korea di Jepang harus mengalami berbagai pengalaman hidup sebagai kaum yang termarginalkan. Stereotip tentang etnis mereka yang selalu tidak baik di mata orang Jepang membuat mereka terkucil dari tatanan masyarakat dan tidak bisa mendapatkan pekerjaan yang layak. Sistem pemerintahan Jepang yang mengatur mereka mau tidak mau membuat mereka harus berasimilasi dengan mengubah nama Korea mereka dan juga belajar bahasa imperial untuk berkomunikasi sehari-hari. Sunja dan keluarganya harus mengubah nama keluarga mereka ke dalam pelafalan bahasa Jepang. Generasi pertama merupakan mereka yang tidak membuang identitas asli mereka seberapa besarnya diskriminasi yang mereka harus hadapi. Mereka tetap hidup bersama dengan masyarakat Jepang sebagai etnis Korea, menekankan posisi zainichi yang pluralis, yang tidak melakukan naturalisasi untuk menjadi warga negara Jepang.

Sebagai generasi yang lahir dan besar di 
Jepang, tepatnya di kawasan ghetto Korea di Ikaino, Osaka, Noa dan Mozasu adalah tokoh yang mewakili generasi kedua zainichi di Jepang. Tokoh Noa mewakili kategori zainichi Korea yang cenderung berorientasi pada Jepang dan asimilasi. Mereka melakukan naturalisasi dengan cara mengubah kewarganegaraan menjadi kewarganegaraan Jepang untuk mendapatkan status sosial yang stabil di masyarakat. Keinginannya untuk meninggalkan kawasan kumuh dan menjadi orang Jepang terwujud ketika mereka meninggalkan keluarganya dan melakukan naturalisasi serta membuang identitasnya sebagai orang Korea setelah mengetahui bahwa darah yakuza mengalir di dalam dirinya. Sementara Mozasu yang tidak memilih jalan naturalisasi untuk bertahan di negara tempat kelahirannya cenderung dapat dilihat mewakili kategori pluralis. Pluralis zainichi Korea tetap hidup bersama dengan orang Jepang dalam masyarakat hegemoni tersebut tanpa membuang identitasnya sebagai orang Korea. Meskipun tidak melakukan naturalisasi dan tetap mendapat stereotip tentang etnisnya, Mozasu tidak membuang identitas Koreanya dan tetap menetap di Jepang. Bisnis pachinko yang kedua tokoh ini tekuni sebagai sumber penghasilan mereka adalah bisnis yang dianggap kotor dan mayoritas dilakukan oleh para pendatang.

Betapa pun sukses, kaya, dan baik zainichi Korea, mereka tetap dianggap kotor dan dipandang sebelah mata. Mereka hanyalah yakuza atau gangster yang menguasai pasarpasar gelap ekonomi Jepang yang dianggap tidak terhormat karena identitas mereka se- bagai kaum yang termarginalkan. Sementara Solomon sebagai tokoh dimunculkan paling akhir, yang sekaligus sebagai generasi terakhir, konstan digambarkan sebagai tokoh yang awalnya menunjukkan karakter individualis zainichi, tetapi pada akhirnya tetap menjadi seorang pluralis zainichi yang tetap hidup di tengah masyarakat Jepang. Ia tetap menerima diskriminasi, tidak jauh berbeda dengan zainichi generasi pertama dan kedua. Sebagai generasi ketiga yang cenderung lebih terbuka dengan dunia modern, ia masih menganggap pachinko sebagai bisnis yang ditakdirkan untuk mereka geluti.

\section{Daftar Pustaka}

Aoki, Kayoko. 2012. "Name and Ethnic Identity: Experiences of Korean Women in Japan." Journal of Asian and African Studies 377391 https://Doi.Org/10.1177/0021909611 419943.

Chan, Tata Francis. 2018. Japan's Pinball Gambling Industry Rakes In 30 Times More Cash Than Las Vegas Casinos. July 26. https:// www.businessinsider.sg/what-is-pachinkogambling-japan-2018-7/?r=US\&IR=T

Cho, Young-Min. 2016. "Koreans In Japan: A Struggle for Acceptance". Law School International Immersion Program Papers (2).

Lee, Jung Hui. 2017. "Superordinate Identity in Zainichi Koreans (Koreans Living in Japan)." IAFOR Journal of Psychology \& the Behavioral Sciences 49-60.

Lee, Min Jin. 2017. Pachinko. London: Head of Zeus.

Lee, Soo im. 2012. "Diversity of Zainichi Koreans and Their Ties to Japan and Korea". Working Paper Series Studies on Multicultural Societies No. 8.

Morooka, Haruka. 2016. Ethnic and National Identity of Third Generation Koreans in Japan. New York: MA the City University of New York. 
Osborn, William James. 2015. Zainichi: How Violence and Naming Determine A Consciousness. MA the., Duke University Graduate Liberal Studies.

Ryang, Sonia. 2014. "Space and Time: The Experience Of The "Zainichi", The Ethnic Korean Population of Japan." Urban Anthropology and Studies of Cultural Systems and World Economic Development 519-559.

Wender, Melissa L. 2005. Lamentation as His- tory. Stanford University Press.

Yim, Jin-Hee. 2019. "Minjin Leeui "Pachinko"e Natanan Jaeilhanin-ui Jangso Damron (Place Discourse of Koreans in Japan: Min Jin Lee's Pachinko)." Asia-pacific Journal of Multimedia Services Convergent with Art, Humanities, and Sociology 271-280.

Wickstrum, Yuuka. 2016. "The Post-War Social And Legal Contexts Of Zainichi Koreans." Okayama University 43-62. 